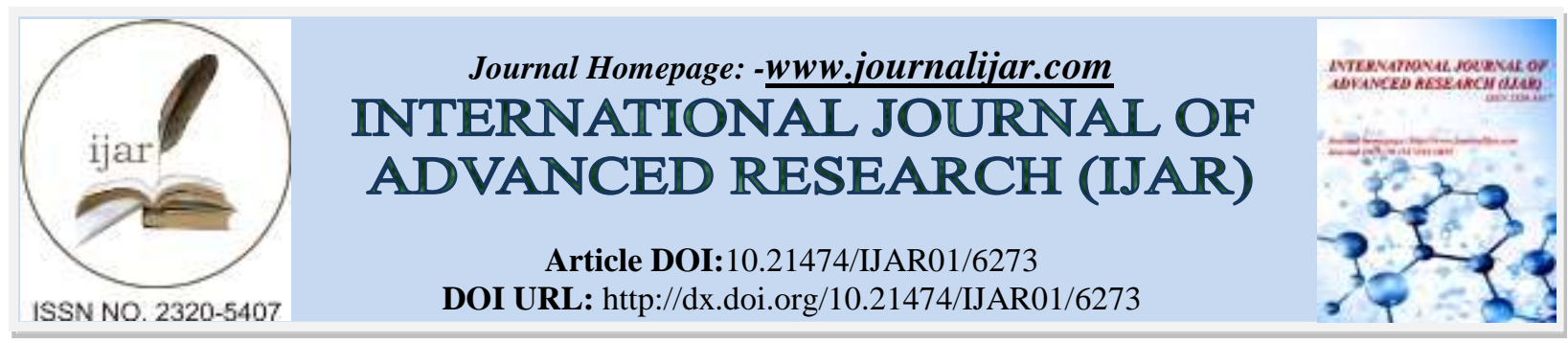

RESEARCH ARTICLE

\title{
EFFECTIVE INTER-CULTURAL COMMUNICATION ON CRUISE SHIPS (STUDY CASED OF INTERCULTURAL COMMUNICATION INDONESIAN CREWS WITH DUTCH CREWS IN HOLLAND AMERICA LINE CRUISES).
}

Arief Nuryana ${ }^{1}$, Prahastiwi Utari ${ }^{2}$ and Sudarmo ${ }^{3}$.

1. PascasarjanaIlmuKomunikasi, FISIP, UniversitasSebelasMaret, Surakarta Jalan Ir. Sutami 36 A, Surakarta (Solo), Indonesia.

2. PascasarjanallmuKomunikasi, FISIP, UniversitasSebelasMaret, Surakarta Jalan Ir. Sutami 36 A, Surakarta (Solo), Indonesia.

3. FISIP UniversitasSebelasMaret, Surakarta Jalan Ir. Sutami 36 A, Surakarta (Solo), Indonesia.

\section{Manuscript Info}

\section{Manuscript History}

Received: 10 November 2017

Final Accepted: 12 December 2017

Published: January 2018

Keywords:-

Effective Communication, Cross-

Cultural, Cruise Ships, Empathy,

Stereotype, Indonesia, Netherlands.

\begin{abstract}
Holland America Line is a cruise ship company where most of its crew comes from Indonesia and the Netherlands. Cultural exchange is very likely to happen because anyone who comes from a country or region will certainly not be separated from the culture in which he was born and raised. With a culture rooted in him, he had to share a room with other people from other cultures. This cultural exchange may be causing a conflict. Conflict can be muted with the birth of awareness that every person should be able to understand the culture of other people of different cultures with him. The process of communication that takes place between people of different cultures is often influenced by several factors: The Act, The Scene, The Agent (Performer), The Agency (Intermediaries), and The Purpose. The factor mentioned above also becomes one of determining an effective communication process. Based on that, we can determine the strategies or methods of communication used in a communication process. Effective communication can be realized if the strategies and methods of communication are used appropriately. Effective communication strategy is very important to be considered in a process of communication. The effectiveness of interpersonal communication was largely determined by factors: openness, empathy, positive feelings, provide support and maintain balance. While the social prejudices that determine the three main factors, namely stereotypes, social distance, and discrimination. The relationship between prejudices to the communication very closely because of the prejudices assumed as the basis for the establishment of communication behavior.
\end{abstract}

Copy Right, IJAR, 2018, All rights reserved.

\section{Introduction:-}

The organization, in his book Littlejohn, believes that every form of society requires organization. Whenever we collaborate to achieve collective action, the organization appears. Organization "symbolic achieve cooperation", and organizational communication is the field that studies how cooperation is achieved or how the organization created. 
Where certain individuals affected more than others, certain groups exert influence over other groups and certain system exerts forces that control or manage other systems. Group communication is one of the most effective ways to share information between membersOrganizational change is a prominent feature of the development of the organization.In this regard, research in the field defines as a proactive search and identification of opportunities for improvements.Good atmospheres in the organization of regular and irregular showed good organization.If the organization is good, then the country or even the small organization atmosphere was good and finally, the class organizational goals can be achieved easily and well.The development of this era almost unblooded in all fields leads to cultural exchange is very likely to happen, because anyone who comes from a country or region will certainly not be separated from the culture in which he was born and raised. With deep-rooted culture within him, one must share space with others from other cultures. These cultural exchanges may cause conflict. Conflict can be mitigated by the birth of awareness that everyone should be able to understand the culture of others who are different cultures with him. According to DeddyMulyana, those very different cultures have different value systems and therefore participate in determining different life goals. The way we communicate is highly dependent on our culture: our language, our rules, and our respective norms. In the communication process between people of different cultures require a more comprehensive understanding. Learning the culture of others is one way to realize that understanding between people of different cultures then the communication will be more effective and the goal of a communication process can be achieved. It is therefore very important to learn what intercultural communication sees its purpose in line with the goal of achieving effective communication. By learning many things and knowing many things about the culture of others, it will create a common meaning in communicating. Obviously different, two people who communicate with no cultural knowledge to each other than have the knowledge and even their own experience of the culture of people who are invited to communicate. The more similar knowledge or experience, the greater the likelihood of similarity of meaning is also greater so as to create effective intercultural communication.

\section{Effectiveness of Intercultural Communication:-}

Different cultures mean different things in conveying ideas, ideas, and different in everyday behavior. Different cultures mean different in communication strategies. A person who only understands one language is the language of his country will not be able to understand when receiving messages in other languages. A man whose culture is so polite to a parent will not accept the disrespect of the elder. A man who in his culture accustomed to being what he is is not going to accept a culture of pretense. Candio Elliot pointed out, self-promotion style may be very little displayed by Native Americans (including native Asians, followed by Hispanics, and style is mostly used by Africans. Formal dress styles may be slightly indicated by Hispanics and native Africans, but very much exhibited by Anglo people (Mixed Americans)The process of communication that takes place between people of different cultures is usually influenced by several factors as proposed by Willian G. Scoot, who quotes Babcot's opinion that there are 5 (five) factors that affect the communication process: The Act, the act of communication wants the use of well-understood symbols and relationships made by humans. In general, the symbols are expressed in language or in certain circumstances other signs may also be used. The Scene as one of the factors in this communication emphasizes its relationship with the communication environment. This scene explains what is done, what symbols are used, and the meaning of what is being said. With the understanding of this scene is what is meant is something that will be communicated with through what symbol, something that can be communicated. The Agent, Individuals who take part in communication relationships are called communication actors. The senders and recipients involved in this communication relationship are examples of such communication actors. And the role often replaces each other in a developing communication situation. The Agency (Intermediaries), the tools built in communication can build the realization of this agency. The tools in addition to intangible oral communication, face to face, can also write communication tools such as warrants, memos, bulletins, notes, letters of duty and other similar. The Purpose, According to Grace in the book Communication Communications and Some Factors Cause Failure by MiftahThoha, there are 4 (four) kinds of purposes are: One, The Functional Goals is a goal that is principally beneficial to achieve goals- the purpose of the organization or institution. Two, The Purpose of Manipulation (The Manipulative Goals); this purpose is intended to mobilize people who are willing to accept ideas that are submitted either in accordance or not with their own values and attitudes. Third, this goal intends to create creative goals. This communication is used to enable a person to express that feeling in reality. Fourth, The Purpose of Confidence (The Confidence Goals); this goal aims to convince or develop people's confidence in the environment. Factors mentioned above also became one of the determinants of a process of communication was running effectively. Based on that also, we can determine the strategy or communication method used in a communication process. 
Effective communication can be realized when the strategies and methods of communication are used appropriately. Effective communication strategies are very important in a communication process. As Onong pointed out: In the military, there is a very famous phrase that says: "The winning strategy is to win the war, while the importance of tactics is to win the battle. The focus of attention of communication experts is important to the communication strategy because the success or failure of communication activities effectively determined by many communication strategies. Communication strategy needs to be paid attention to the maximum because its function is so urgent. Onong illustrates that the function of communication strategy is double that is: First, disseminate communication messages that are informative, persuasive and instructive systematically to the target to obtain optimal results. Second, bridging the "cultural gap" due to its ease of acquisition and ease of operation of mass media that is so powerful, that if left unchecked will undermine cultural values. Now, incoming information from outside is not only a positive thing but also followed negative things in it like a free association that has become a habit in the western countries. Western cultural values that are inconsistent with Indonesian society can be prevented by appropriate messaging strategies. To that end, the state has an obligation to protect its citizens from things that will have a negative impact. Nowadays, the government's step by banning porn sites on the internet is one of the positive steps that must be constantly monitored so that the implementation becomes maximal. The way out that also needs to be taken care of is making the right communication strategy. The steady communication strategy requires some of the components described by Onong that everything will be linked to components which are the answer of Laswell's who (who is the communicator?) Formula, what says (what message did he say?), in which channel (what medium which to use?), to whom (who is the communicant?), with what effect (what effect is expected? and added again to the question when, how and why is this done?. In communicating with people of different cultures, finding the right strategy is also very important. Especially if the parties who make the communication process want to make a maximum result that changes, both in terms of cognitive, effective to psycho-motor. One part of the success of a strategy is to use the right method of communication. According to AloLiliweri, there are three main methods of communication namely: Informative communication, Communication methods that discusses information about people, objects, places, events, processes, situations and conditions, problems. Someone who communicates conveys a message that is informative to someone else, this method is intended to bring a person closer through information that has been commonly understood and known by others. Persuasive communication, this method of persuasive communication more quickly and appropriately influence or change public attitudes and perceptions. Coercive communication This method explains that in order to persuade a person or group of people to change their attitude, the communicator will send a message by pressing, forcing, or giving instructions even with 'brainwashing' tactics. One way to make a person change or more quickly change more precisely is by using persuasive communication methods. According to De Vito, there are two goals of persuasion talks: Talks to strengthen or change attitudes or beliefs many talks are aimed at strengthening existing attitudes or beliefs. For example, people who listen to religious lectures usually have already embraced the religion. Meanwhile, talks designed to change attitudes and beliefs are more difficult. Most people resist change. Therefore it is necessary to consider the following principles: One, Estimate carefully the level of attitudes and beliefs communicant. Two, Try to change little by little. Three, Give a convincing reason to make the communicant believe what you want. Talks to stimulate action there are several principles to note: One, Be realistic about what you want the communicant to do. Two, Show your own willingness to do the same. Three, Emphasize the specific benefits of this behavior for communicant In the process of persuasion is known some communication models described by Tommy that generally known two models of persuasion are: 1) Psycho-dynamic model; according to this model communication messages will be more effective in persuasion if have the ability to change the psychological interests or individual attention in such a way, so that individuals will respond to communication messages in accordance with the will of communicators. The dynamic psycho model develops on both theoretical and empirical grounds. Important theories of motivation, perception, learning, and even psychoanalysis have provided the way by which attitudes, opinions, fears, self-concept of source credibility and some other variables have a relationship with persuasion. Sociology-Cultural Model; The sociologycultural model in the persuasion process is based on the assumption that communication messages can be used to direct individuals to accept the symptoms that the group has supported as the basis of the individual to act. This model in the process of persuasion can be described as follows. With these various methods, effective communication can be achieved. Effective communication can be seen in several categories, as revealed by AloLiliweri that the categories of effective communication habits are; Space sensitive and distance sensitive; understanding communicators and communicant about how should understand the space and distance at the time of communicating, including the physical distance when Messages are persuasive Limitations of Sociology-Cultural Process Groups Forms the definition For social behavior for members Produce behavior change in progress communication. Not paying attention to or even breaking physical space or distance will result in communication failure or even private conflicts. Sensitive to communication and language culture; Intercultural differences 
influence the interpretation or meaning of messages contained in language, signs and symbols (both verbal and nonverbal). The keyword for creating the effectiveness of intercultural communication is to understand the same meaning for verbal and nonverbal messages. Can appear with typical clothes; in intercultural communication, one way to create effective communication is to choose to appear in material culture, such as using clothing from the local culture. Can taste food and drinks; the effectiveness of intercultural communication requires people to taste the typical food of other people's culture, even cooking and how to serve it. Be sensitive to relationships; the effectiveness of intercultural communication requires everyone who communicates to be sensitive to relationships. Every culture determines exactly how people should relate in different contexts. Be sensitive to values and norms: Successful intercultural communication can be achieved only if a person comes to a different place of culture with him by understanding and living the local cultural norms.

Differences between ethnic, inter-ethnic, describe also differences in values and norms through their orientation of life, ie orientation towards individuals, families, groups, duties, offices, views of honesty, loyalty, and compassionate compensation. Be sensitive to beliefs and attitudes; effective intercultural communication is determined by how people understand the beliefs and attitudes of other people's cultures. The association with people of other ethnic groups and religions will be determined by the extent to which a person exhibits a certain attitude that cares about the beliefs of others. There are 17 intercultural communication tips provided by the center for intercultural learning of the Canadian Foreign Service Institute, in order to create effective intercultural communication: Recognizing that language skills are not necessarily intercultural competencies. Look for feedback to see if others understand what you really mean. Paraphrase back to the sender what message you understand about them to be more comprehensive. Avoid expression, jargon, acronym, and metaphor that are tied to your cultural references. Confirm your understanding of a metaphor or analogy when listening from someone from another cultural perspective especially when understanding it. Make sure the interaction and decision-making patterns include everyone. Give time to speak in mother tongue so that people can explore and define what they want to say without paraphrase (revealing in their own language) into the spoken language. Use the red flag system, recognize it, understand, whenever you react both positively and negatively to what is being communicated. Be careful your reaction may not match with other people's communication. Consider seriously what, it seems suggested, be careful of others may be angry as well. Listen actively until somebody finishes talking, pay attention to speech patterns and ups and downs either when changing the topic or being mispronounced. How you say it is as important as what you say. Try listening to the silence, meaning different things from different cultures. See before reacting. Look for interpretations or cultural informants. Use pictures, diagrams or story-stories to convey messages. Try to learn the logic inherent in other cultures-that is, the correction between appearance, behavior, and values. Be calm, calculate the risks and learn from your experience the sensitivity that a person from a culture exhibits to another culture will create a harmonious interaction between the two. Harmonious interaction creates a common understanding of the meaning of the message it receives. With the similarity of meaning, then intercultural communication becomes effective. The concept of inter-ethnic communication from David K. Berto and JosepDevito, that they interpret intercultural communication as a form of interpersonal communication from communicators and communicants of different cultures. The effectiveness of interpersonal communication is largely determined by factors: openness, empathy, positive feelings, support, and maintaining balance, while social prejudices, which determine the three main factors of stereotypes, social distance, and attitudes of discrimination. The relationship between prejudice and communication is intimately linked because prejudices are assumed to be the basis for the establishment of communication behavior.

\section{Purpose and Research Method:-}

Holland America Line is one of the largest cruise ship industry Consisting of 32 Nationalities crew working here. For this study, the researchers only took the subject of research are Indonesian crew and Dutch crew as the two largest crew groups in Holland America Line. This study uses a qualitative method. A qualitative approach is used to describe a reality and social conditions within the organization. According to Nasution (in Sudjarwo, 2001: 25), a qualitative approach is an approach based on field realities and what respondents experience. To reveal the phenomenon of Indonesian crew communication with other crew, researchers used qualitative research methods with symbolic interactionist approach. A subjective approach to ethnic identity can be traced down to Cooley's (1902) and Mead (1934) definitions of 'self'. This approach criticizes the positivistic approach in the sense that it limits the possibilities of human behavior that can be learned. In contrast to the positivistic approach, which views individuals as passive and changes caused by social forces outside themselves, the phenomenological approach considers that human beings are far from passive (Mulyana and Rachmat, 2000: 155). The essence of symbolic interaction theory is the theory of the 'self' of George Herbert Mead, which can also be traced down to the definition 
of Charles Horton Cooley. Mead, like Cooley, considers that self-concept is a process derived from individual social interactions with others (Mulyana, 2001: 73). Data collection techniques in this study were conducted in three ways, namely: (1) in-depth interviews directly, face to face with the crew who was vacation back to Indonesia (2) in-depth interviews, with email correspondence and (3) use of documents. Researchers observed the phenomenon of intercultural communication that occurred in the ship Holland America Line. In the data retrieval, researchers conduct conversations that are not planned and not formal. Conversations with people who are considered as informants can be used as data that can support the research in question. Data collection techniques with the open or in-depth interview either directly or correspondence via email, which gives freedom for informants to give, views freely (Koent-jaraningrat, 1989: 30). This interview allows the researcher to ask questions in depth. Therefore, to complement the data of this study, especially in an effort to obtain accurate data about this research, researchers conducted interviews with informants. In this study, interviews to be used are in-depth interviews or unstructured interviews. Unstructured interviews are similar to informal conversations (Mulyana, 2001: 181). This type of interview is done because it is flexible, the composition of questions or words can be changed when the interview is conducted, tailored to the needs, and conditions of the informants encountered. Researchers themselves become the core instrument in collecting this data. This is done because researchers can explore the focus of research that not only accepts what the informants say and experience, but more deeply, in order to reveal the hidden things deep within the informant. Interviews conducted with several techniques, namely: first, unstructured, meaning that researchers will be free and free to ask things related to the focus research. Second is not frank, culture. Such enculturation takes place through them (Sutaryo, 2002: 64). Furthermore, accreditation according to Koentjaningrat in Ruswanto (2004: 314) as a process in which individuals or citizens of a society is faced with the influence of other cultures and foreign. In the process, some partially take over selectively little or many elements of the foreign culture, and some attempt to resist that influence. Cultures that have been formed during enculturation may change when influenced by the outside culture through the process of acculturation. According to Kim, the process of acculturation will begin when an immigrant enters the indigenous culture. This process will continue as long as immigrants make direct contact with the indigenous socio-cultural system. All the acculturative powers and potential acculturation of immigrants before immigrating interactively will affect the course of changes in the acculturation process of immigrants. The acculturation process may not proceed straight and smooth, but move forward toward hypothetical assimilation is a perfect assimilation (Mulyana and Rachmat, 2000: 146). The similarity between indigenous immigrant culture and indigenous culture is an important factor that can support the potential for acculturation. An immigrant from Canada to America, for example, will have greater acculturation potential than an immigrant from a Southeast Asian country. According to Kim, a person's age during immigration will be related to the potential for acculturation. Older immigrants will experience many difficulties in adapting to new cultures and they are slower in acquiring new cultural patterns. Immigrant education background before immigration will facilitate acculturation. Other factors that strengthen the potential of acculturation are personality such as friendship, tolerance, willing to take risks, openness (Mulyana, 2005: 145).

Individuals who come to an entirely new territory according to Gudykunst and Kim, "Gradually, strangers begin to detect new patterns of thinking and behavior and to structure a personally relevant adaptation to the host society. Merely handling the transactions of daily living requires the ability to detect similarities and differences within the new surrounding. The stranger thereby becomes acquainted with, and adapt, some of the norms and values of salient reference groups of the host society" (Gudykunst\& Kim, 1992: 215).

For Indonesian crew who work to an entirely new place, they must keep their survival and always strive to gain acceptance from the indigenous population as part of its community members. In touch with an entirely new culture is a situation that can not be avoided by the Indonesian crew on the Holland America Line. In these circumstances of course many problems arise. The difficulties experienced by immigrant communities, in addition to verbal and nonverbal communication patterns, are also a way of recognizing and responding to the common communication rules in the new culture they enter. Immigrants often cannot stand the hidden cultural dimensions of the population that affect what is perceived and how it perceives it, how to interpret observed messages, how to express thoughts and feelings appropriately in different relational and different contexts. These differences often hinder the mutual understanding between the immigrants and the ethnic residents. A person or a community group will adapt to a new environment if they will stay for a long time in this case an Indonesian crew must stay in a cruise ship environment within a minimum of 1 year. They need to build a new life and become members of the indigenous community. (Mulyana\&Rachmat, 2000: 138). Every culture has a language so that members of the culture can communicate with each other. Language is influenced by culture and so does language reflect cultural values. Stonequist mentions that the process of adaptation is divided into three situations: (1) assimilation into the dominant group, (2) 
assimilating into subordinate groups or (3) accommodating and reconciling two societies (in Kim, 2001: 24). The process of assimilation generally occurs in the human groups of the majority social groups and some groups of minority social groups. In this case, usually the minority social group changes the distinctive characteristics of its culture and adapts it to the culture of the majority social group in such a way that it gradually loses its personality and enters the majority culture (Agusyanto, 2006: 26). To protect themselves from the assimilation process some Indonesian crew still maintain their ethnic identity by holding their cultural performances on cruise ships (crew group from Bali and Madura). Such crew groups prefer to integrate rather than assimilate as revealed by Martin and Nakayama: Integration occurs when migrants have an interest in both interacting with their other cultures and languages. This differs from assimilation in that it involves a greater interest in maintaining one's own cultural identity. Immigrants can resist assimilation in many ways - for example, by insisting on speaking their own language in their home. (Martin \& Nakayama, 2000: 274) (Integration occurs when migrants have a desire to preserve their original culture and language, on the other hand, in their daily lives they interact with other groups.The difference with assimilation is that they are more interested in maintaining their cultural identity. The Indonesian crew can avoid themselves from assimilation in various ways one of which is to attempt to always speak with the language of origin while in the environment is part of the Indonesian crew adaptation to the environment on the cruise ship. Language Selection Used in Inter-crew Interaction on Cruise Ships and Attitudes Built in Inter-Ethnic Behavior. Several moments or activities related to cooperation became factors that strengthen the cohesion among crew on Holland America Line ships, among others, the celebration of the anniversary of the State of both Indonesia and the Netherlands is a day where every crew merged to follow the independence ceremony as an invited guest and ended by eating together with a typical menu of origin countries that are celebrating such independence on board a cruise ship. They are generally capable of carrying out both Indonesian and Dutch cultures at once, so this mixing of cultures creates a new culture. Indonesian crew in general have adapted to the culture on cruise ships that are so affected by European culture that when interacting with Europeans there is no more significant obstacles. This is in line with the statement that researchers get from all informants who say there is nothing special to be prepared when going to interact with people of different ethnicities on cruise ships. This is because all the crew who are there have met the necessary requirements in conducting intercultural communication such as: 1) the attitude of respect for other members of the culture as human beings; 2) an attitude of respect for other cultures as they are, and not what we want them to be; 3) an attitude of respect for the right of other members of the culture to act differently from the way we act; 4) A competent crosscultural communicator must learn to enjoy life with people from other cultures (Rumondor in Anugrah and Kresnowiati, 2008).

\section{Results and Discussion:-}

Effective communication can be realized when the strategies and methods of communication are used appropriately. Effective communication strategies are very important in a communication process. As Onong pointed out: In the military, there is a very famous phrase that says: "The importance of strategy is to win the war, while the importance of tactics is to win the battle. The focus of attention of the communication expert is indeed important to the communication strategy. In the process of persuasion it is known some communication models described by Tommy that generally known two models of persuasion are: 1) Psychodynamic model; according to this model communication messages will be more effective in persuasion if have the ability to change the psychological interests or individual attention in such a way, so that individuals will respond to communication messages in accordance with the will of communicators. Psychodynamic models evolve on both theoretical and empirical grounds. Important theories of motivation, perception, learning, and even psychoanalysis have provided the way by which attitudes, opinions, fears, self-concept of source credibility and some other variables have the relationship with persuasion Intercultural communication as a form of interpersonal communication communicators and different cultures. The effectiveness of interpersonal communication is largely determined by factors: openness, empathy, positive feelings, support, and maintaining balance, while social prejudices that determine the three main factors of stereotypes, social distance, and attitudes of discrimination. The relationship between prejudice and communication is intimately linked because prejudices are assumed to be the basis for the formation of communication behaviors and interpretations of the important points in which individuals will act, and group action consists of individual actions. As a theory, symbolic interactions try to see the social reality created by humans through the exchange of symbols. This symbolic interaction theory seeks to construct a sense of self, action, and object. Then Blumer further developed Mead's ideas in five basic concepts: self-concept, the concept of action, object concept, social interaction concept, and collective action concept (in Veeger 1993: 224-227). The First is the concept of 'self', Man is not merely an organism that moves under the influence of stimuli from both inside and outside, but an organism having a self. In interacting with oneself, man is able to view himself as the object of his mind, associate or interact with oneself. Being in shaping action, humans engage in internal dialogue in drafting concepts and strategies for 
connecting with the outside world. Thus, man is not a creature acting on the outer environment, but acting on the outcome of his inner interpretation. The result of this internal interaction will lead to action.

Second, the concept of 'action' formed within and through the process of interaction with oneself. Human action is not solely a biological reaction, but the result of its construction. Therefore, the man himself is the constructor of his behavior. Before acting humans must set goals, describe the direction of his behavior, estimate the situation, record and interpret the actions of others, check himself and so on. Related to this, Mead concludes that man is seen as an active organism that has rights to the object that he modified. Actions are seen as behaviors shaped by the offender, instead of the response they get from within themselves.

The Third is the concept of 'object'. Humans live in the midst of objects. The object can be physical, or something abstract. The essence of the object is not determined by its intrinsic traits. It is in the interest of the person and the meaning imposed on the objects. The object for Mead is something that can be appointed or referred to, both real and abstract. Symbolic interactionism views the life of human groups as a process in which objects are created, confirmed, transformed and even discarded. Human life and behavior are inevitably changed in line with the change-change that takes place in the world of their objects.

The Fourth is the concept of 'social interaction'. Interaction means that every participant moves them mentally into someone else's position. Humans try to understand the purpose of action done by others so that interaction and communication are possible. Interaction is not only going through the motions only but also through the symbols that need to be understood and understood its meaning. In symbolic interaction, people interpret and interpret the movements of others and act in accordance with that meaning.

The Fifth is the concept of 'collective action' born of the actions of each participant which is then matched and adapted to each other. The essence of collective action is the harmonization and fusion of meanings, purposes, thoughts and attitudes. Therefore, the social interaction takes a lot of time to achieve harmony and fusion (Soeprapto, 2002: 161-164). Symbolic interaction theories focus on the interaction between individuals and groups, in which individuals interact face-to-face (face to face) by means of symbols, in which it contains signs, signals and most importantly through words in writing and orally. A word has no meaning inherent in the word itself, but it is just a sound, and it will have meaning that people will agree that it contains a special meaning. This symbolic thought will essentially set us free from the restrictions of human experience only on what we really see, hear or feel. The theory makes us constantly think of objects symbolically (Soeprapto, 2001: 68-70) of the theory of symbolic interaction is the theory of the "self" (self) of George Herbert Mead, which can also be traced down to the definition of self from Charles Horton Cooley. Cooley (1922) was the first modern thinker to introduce the notion of "self that looks like a mirror". According Cooley self describes a perception itself in the minds of others and in the behavior of affection. We use others as mirrors to show who we are. We imagine how people view us and how they judge us, and the appearance and judgment of these decisions becomes a picture of ourselves. In the disciplines of sociology, anthropology, psychology and history are often studied ethnic identity. Other terms similar to ethnic identity include ethnicity (ethnicity) or cultural and racial self-concept. These terms are sometimes used identically or have the same meaning by experts. The meaning of the concept of ethnic identity is not always explicit in these studies but is often related to and or implied in the study of acculturation, assimilation, adaptation of an ethnic group in a foreign country (Mulyana and Rachmat 2000: 151). The approach to ethnic identity is split into two. First is the subjective perspective that defines ethnicity as a pros-ice where people experience or feel themselves as part of an ethnic group and identified as such by others, and focus on the attachment and belonging that the ethnic group perceives (Mulyana and Rachmat 2000: 152). Furthermore, minority cultures are influenced by the dominant culture from the pressures of the cultural environment itself, (Barth, 1988: 10), there are two views: First, cultural boundaries can survive even if the tribes mingle. In other words, inter-ethnic differences are not determined by the absence of intermingling, contact and information exchange, but rather due to social processes of separation and unification, so that different categories are maintained despite the exchange of membership participation among ethnic units within the journey of one's life. Second, there can be found a steady, durable, and important social relationship between two distinct ethnic groups, which usually occurs because of the different ethnic status, is not determined by the lack of interaction and social acceptance, but on the contrary it is realized by the formation of the social system certain. In other words ethnic groups are defined by boundaries and possessed or characterized by the group itself, which then form its own pattern, besides the cultural boundaries can survive even between two ethnics can blend. The existence of ethnic differences in society is more due to the process of separation and unification so that differences can be maintained in the course of one's life. In addition, social relations in society for so long and 
run in such a way in multi-ethnic organizations usually occurs more due to the presence of ethnic status. Similarly, each of these different ethnic groups is constituted by the formation of a social system within the organization. The object of this research is the Indonesian crew at the Holland America Line Cruises that undergo integration and adaptation processes in various social environments. To explore field data in more depth and relevance, the informants were chosen purposively.This is based on the data needs the researcher wants. The selected informant criteria are as follows: (1) the principal informant is the officers who formally have the task of managing the organization that is the responsibility. This informant is expected to know matters relating to the social culture of the organization; (2) Key informants are crews of each ethnic who experience or work on the Holland America Line Ship for at least 2 years; and (3) Participant informants selected from Indonesian crew who have been working at Holland America Line Cruise Line for at least 10 years (adaptive) who are not officers but know and understand organizational culture.

\section{Conclusion:-}

The interaction between Indonesian crew on Holland America Line cruise ships as immigrants with European crew in general, especially with Dutch crew who became the origin of the State flag as the identity of the ship as a native in the Holland America Line has been going on since the 1970s when the Company began to hire and hire crew from Indonesia. After passing that period there has been a mutual adaptation between the two groups of the crew. People from Indonesian crews have accepted the customs of Dutch crew and other crew such as the use of their native language while interacting with other crew, performing European customs, making and consuming European specialties. While the European crew community, especially the Netherlands, many of whom mastered the Indonesian language, and consume Indonesian food, also participated in watching Indonesia crew show which is the night of crew Indonesia performs performing arts dances and singing typical Indonesia which is held every two weeks. The relationship between crew so far is quite harmonious without any meaningful conflicts. This inter-ethnic relationship takes place without any significant obstacles because each ethnic have to accept each other for what it is. That by changing behaviors and attitudes can actually change in the organization; meaning is an important result in the communication process. When there is a social world of meaning in which it will create symbols that are defined by the interaction. Symbolic interaction teaches that as people interact with one another from time to time, they come to share the meaning of certain way and similar When Groups are together, the certain energy is portrayed in each group member. The energy can go towards the task or to an interpersonal obstacle. Raymond Cattell used the term "synergy" for this group effort the interaction has two dimensions, content and relationships content dimensions deal with information related to the task. Relationships dimension are factors such as attitudes and known perceptions in the organization. These could block the goal of the message. In the orientation phase, this is where the task is presented and individuals begin to persuade other members toward their feelings. Based on the findings in the field, in this research report can be submitted suggestions as follows that Each group crew must remain mutually respect other cultures, this situation is expected to reduce the potential conflicts that can occur on the cruise ship.

\section{Acknowledgement:-}

I would like to express the deepest appreciation to my favorite lectures who always supporting me, Dra. PrahastiwiUtari, Ph.D., and Drs. Sudarmo, MA., Ph.D., who has attitude and the substance of a genius; they continually and convincingly conveyed a spirit of adventure in regards to research and scholarship and excitement in regard to teaching. Without their guidance and persistent help, this paper would not have been possible.

In addition, thanks to you to all my dearest friend of Holland America Line Crews who support me all the way with your time and knowledge and enthusiasms, had the lasting effect. "Jalas Veva Jaya Mahe" 


\section{References:-}

1. Abdullaev 2011 Organizational and Technological Factors Influence the Efficiency of Building Management ISSN/EISSN, 2011

2. Agusyanto, R. (2006). Pengantarantropologi. Jakarta: PusatPenerbitanUniversitasTerbu-ka.

3. Alvesson, M year 2002 Understanding Organizational Culture. London Sage.

4. Anugrah, D danKresnowiati. (2008). Komunikasiantarbudaya, konsepdanaplikasinya. Jakarta: JalaPermata.

5. Ardial, (2014), Paradigmadan Model PenelitianKomunikasi, Jakarta; BumiAksara

6. Aura Condreanu (2010) “A Matter Of Individual And Group Behavior Transformation” Organizational Change Management ISSN 2068-9403 Volume 1, Journal of Defense Resources Management

7. Aura Condreanu (2010) Organizational Change; A Matter of Individual and Group Bahavior Transformation Persuasion Communication. Deaconualecxandriaana, Rascalavinia et all (2010)

8. DeddyMulyana\&JalaluddinRahmat, (2000)Komunikasiantarbudaya: PanduanBerkomunikasidengan OrangOrang Berbeda, Bandung: RemajaRosdakarya

9. Effendy, OnongUchyana, (2007) IlmuTeoridanFilsafatKomunikasi, Bandung: Citra AdityaBakti

10. Grigore Ana, Maria Badea, Florica, et all, 2010 Modern Instruments for Measuring Organizational Performance ISSN/EISSN 2010

11. Gudykunst, W. B. dan Kim, Y. Y. (1992). Communicating with stangers (an approach to in-tercultural communication). New York: Mc-Graw Hill Inc.

12. Jacobs, G., Van Witteloostuijn, et all year of (2013) Frameworks of Organizational Change

13. Kluckhohn, C (1951) Values and Values Orientation in Theory of Action; Exploration in Definition and Classification.

14. Koentjaraningrat. (1993). Masalah kesukubangsaan dan integrasinasional. Jakarta: PenerbitUniversitas Indonesia.

15. LiliweriAllo, (2003) KomunikasiSerba Ada SerbaMakna, Jakarta : Predana Media Group,

16. LiliweriAllo, (2003) Makna Budaya dalam Komunikasi AntarBudaya, Yogyakarta: Lkis,

17. Liliweri, Alo. (2009) Dasar-Dasar KomunikasiAntarBudaya, Yogyakarta: PustakaPelajar

18. Martin, G, (2006) Managing People and Organizations in Changing Contexts Butterworth-Heinemann

19. Martin, N. Judith, dan Nakayama, K. T. (2000). Intercultural communication in contexts. New York: Mc.Graw Hill.

20. Mulyana, D (2005). Komunikasi efektif suatu pendekatan lintasbudaya. Bandung: Remaja Rosdakarya.Poloma, M. M.

21. Mulyana, D. (2000). Ilmu Komunikasi suatu pengantar. Bandung: RemajaRosdakarya.

22. Mulyana, D. (2001). Metode penelitian kualitatif, paradigmabaruIlmuKomunikasidanIlmuSosiallainnya. Bandung: RemajaRosdakarya.

23. NebojsaJanicilecicv ISSN year 2012 The Influence of Organizational Culture on Organizational Preferences towards the Choices of Organization Change Strategy

24. Organizational Form, Population Dynamics, and Institutional Change Authors David J. Tucker-Mcmaster University Jitendra year 1990

25. Perloff, R, M (2003) The Dynamics of Persuassion Communicationand Attitudes in the $21^{\text {st }}$ Century

26. Ritzer, G. dan Goodman, J. D. (2004). Teorisosiologi modern. Jakarta: Prenada Media.Rumondor, A. H. (2005). Komunikasi antarbudaya. Jakarta: PusatPenerbitan Universitas Terbuka.

27. Schwartz, S. year of 1996 Values Priorities and Behavior: Theory of integrated Value Systems.

28. Soeprapto, H. R. R. (2002). Interaksionis simbolik. Malang: Averroes Press.

29. Spector, B. (2007) Implementing Organizational Change; Theory and Practice. New Jersey: Pearsons P.29

30. Stephen W Littlejohn and Karen A. Foss (2011) Theories of Human Communication $10^{\text {th }}$ edition,

31. Sudjarwo. (2001). Metodologi penelitian sosial. Bandung: Mandar Maju.Suparlan, P. (1989).

32. Suprapto, Tommy, (2006) Pengantar Teori Komunikasi, Yogyakarta: Media Pressindo

33. Sutaryo, (2005) Sosiologi Komunikasi: PerspektifTeoritis, Yogyakarta: ArtiBumiIntaran,

34. Turner, J. H. (1991). The structure of the sociological theory. Belmont CA: Wadsworth Publishing Co.

35. Veeger, K. J. (1993). Realitas sosial: refleksi filsafat sosial atas hubungan individu masyarakat dalam cakrawala sejarah sosiolog. Jakarta: Gramedia. 